\title{
Participation of Society in a Reconstruction Fund Model
}

\author{
Sudmitted $24 / 2 / 181^{\text {st }}$ revision $21 / 7 / 18,2^{\text {nd }}$ revision $23 / 10 / 18,3^{\text {rd }}$ revision $9 / 2 / 19$, accepted $20 / 3 / 19$
}

\section{Sriharini $^{1}$}

\begin{abstract}
:
Purpose: The study examines the rehabilitation and reconstruction of a community and community-based settlement post-earthquake in Banguntapan District, Bantul Regency, Special Region of Yogyakarta.

Design/Methodology/Approach: The research uses qualitative analysis. Procedures used in data collection included observation, interviews and existing documentation. To ensure the validity of data, the author used triangulation. The analysis method used is qualitativeinteractive analysis, which consists of three activities that run simultaneously, namely; data reduction, data presentation, and conclusions.

Findings: The results show that the basic approach adopted by Re-Kompak JRF is the participation of the community through the combination of development based on community groups and value-based development.

Practical implications: Development based on community groups means to position the people in the community as the main actors who are believed to be able to take important decisions about their lives and be able to organize their settlement recovery with appropriate assistance.

Originality/Value: Development is based on value, meaning that settlement development must be a means of developing values toward social capital development.
\end{abstract}

Keywords: Management, disaster, community participation.

Paper type: Research article.

${ }^{1}$ Sunan Kalijaga State Islamic University of Yogyakarta, Email: sriharini1515@ gmail.com 


\section{Introduction}

The impact of an earthquake (Sunarto, 2008) always results in enormous loss of both life and property for human beings. The impact caused by earthquake events have the highest percentage of damage or the most severe compared with other types of natural disasters. The tragedy of the earthquake that occurred on Saturday morning claimed 5,760 lives (4,697 in DIY and 1,063 in Central Java) and damaged 388,758 houses (186,592 in DIY and 202,166 in Central Java), including 187,474 houses which collapsed. In addition to swallowing thousands of lives and tearing down hundreds of thousands of houses, the impact of the quake also damaged public facilities and infrastructure such as transportation, energy, water and sanitation and telecommunications. The earthquakes that occur, in addition to consuming many lives, loss of property, also disrupt the joints of human life so as to cause social, economic and psychological disorders of society (Naryanto et al., 1999).

The definition of disaster management is a set of policies and administrative decisions and operational activities linked to various stages of all disaster levels. Dunn (1994) explains that the cycle of disaster management is grouped into three stages: first the pre-disaster stage which includes prevention, taming and preparedness activities. Second, the current phase of the disaster including emergency response and relief activities. Third, the post-disaster stage which includes recovery and development activities.

According to Locander and Hamilton (2012), prevention, mitigation and preparedness activities aim to reduce the impact of a disaster before the disaster. The emergency response period usually takes about two weeks to three months after a disaster occurs. While the recovery period (repair, rehabilitation and reconstruction) usually lasts for about five to ten years or even more (Hofstede, 2014). According to Hoeffler and Keller (2013) disasters tend to reflect the following characteristics: (1) Disturbance to normal life pattern; (2) Impacts on humans such as loss of life, injuries, suffering and health problems; (3) Impact on social structures such as damage to government systems, buildings, communications and public services; (4) The community requires protection, food, clothing, medical assistance and social assistance.

Earthquakes are one of the most frequent natural disasters in Indonesia. Earthquakes are vibrations or sudden shifts that occur beneath the earth's surface. Ordinary earthquakes are caused by the movement of the earth's crust or the earth's plates (Don \& Leet, 2006). According to Karnawati (2007), earthquake characteristics include (1) An event that cannot be prevented but whose impact can be minimized; (2) When or where the events happen cannot be predicted, but with geostatistical data can be estimated; (3) Prone areas can be predicted or mapped; (4) The affected areas are generally large and can cause regional damage; (5) May cause a tsunami when earthquake magnitude $>6.5 \mathrm{SR}$. One of the theories used to explain how tectonic earthquakes occur is the elastic rebound theory proposed by Reid in 
(Sudibyakto, 2000). This theory simply explains the following. In the shell of the earth there is always a geological activity which results in the relative movement of one mass of rock in the earth's crust to the other. When the voltage that occurs in the rock exceeds its strength, the rock will be destroyed in the weakest region called the fault (Anderson, 2000).

Mubyarto \& Kartodirjo (1981), define participation as, a willingness to help the success of each program in the capacity of everyone without sacrificing self-interest. While Chase et al., (2004) suggest that the meaning of participation is a statement and energy of a person in a group situation that encourages them to develop the power of thought and feeling for the achievement of common goals and responsibilities towards a particular goal. Mikkelsen (2003) inventoried five kinds of participation: First, participation is the voluntary contribution from the community to the project without taking part in decision making. Second, the community increases the willingness to accept and the ability to respond to development projects. Third, participation is an active process, taking the initiative and using its freedom to do so. Fourth, participation is the consolidation of dialogue between communities. Fifth, participation is voluntary engagement by the community

\section{Research Methodology}

The approach used in this research is qualitative. This research puts more emphasis on the disclosure of meaning and process with natural background as the source of direct data (Moleong, 2006). Qualitative research has some natural background, as direct data source, and the researcher is a key instrument (Yin, 2003). Researchers enter a setting that has norms, values and rules, and researchers should understand and study cultures (Bogdan \& Biklen, 1988) This study used three techniques, namely: (1) in-depth interviews, (2) participant observation, and (3) documentation study. These three techniques are basic techniques in qualitative research. According to Miles and Huberman (1992), data analysis consists of three activities that occur simultaneously, namely: data reduction, data presentation, and withdrawal of conclusions or verification (Mulyaet et al., 2016).

\section{Research Result and Discussion}

\subsection{Research Results}

This program is called the RE-KOMPAK JRF project. RE-KOMPAK JRF is an extension of the Rehabilitation and Reconstruction of Community and CommunityBased Settlements Java Reconstruction Fund. In addition to government funds derived from the State Budget, JRF offers a lot of assistance in rebuilding homes that have collapsed and are severely damaged. The stages or flow of the JRF ReCompact project implementation are as follows: First, the preparatory phase, consisting of Re-Kompak orientation, volunteer formation, resettlement volunteer training and committee establishment. Second, the general planning stage, 
comprising of data collection and mapping, compilation or review of settlement plan and environmental spatial plan. Third, the stage of environmental development, environmental planning (sketches of spatial and basic infrastructure and cost plan), preparation of activity committee, disbursement and implementation of environmental development. Fourth, the stage of housing construction, consisting of preparation of settlement groups, house planning, disbursement and implementation of housing construction.

The emphasis of JRF Re-Compact activities are on: (a) Organize disaster-affected people and consolidate them into a solid community in residential areas. Considering that community development and settlement are the main domains of women or mothers, it is necessary to hold special meetings of women's groups so that women aspirations are well accommodated; (b) Conducting self-help surveys, in the form of family data of disaster victims, land tenure limits, profiles of disaster victims, damage conditions, potential data and so on; (c) Improving the ability of community groups to plan and conduct a participatory rearrangement of the environment and houses; (d) Increase the ability of community groups to plan and implement rehabilitation and reconstruction of settlements; (e) Increase the ability of community groups to explore, develop and mobilize community resources; and (f) Bring together organized societies with resources available outside the community.

In the post-earthquake rehabilitation and reconstruction activities, the JRF ReCompact activity stage includes three important things: preparation, planning and implementation. First, the preparation phase involves consultation and dissemination of project concepts and mechanisms to stakeholders, from the central to regional levels, in order to have a common vision, mission and project strategy, and coordination and alignment of activities prior to the Re-Kompak project. Second, the planning stage includes the establishment of development institutions, self-help survey, orientation and education and community training, self-help surveys, identification of grant recipients or beneficiaries, preparation of resettlement rehabilitation and reconstruction plans. Thirdly the preparation of cost budget plan, formulation of development work plans up to funding proposal stage.

With regards to the accountability of the post-earthquake rehabilitation and reconstruction program through the RE-KOMPAK JRF program, there are three points to be mentioned: First, quality assurance. In the context of rehabilitation and reconstruction of community-based houses, the quality of the resulting building is determined, among others, by the ability of the community, the performance of the companion and the conducive policy climate. Quality assurance in RE-KOMPAK JRF program is implemented throughout the process through various steps: public test to be transparent, continuous monitoring, implementation of control card and preventive measures in every DBR disbursement. Thus, the whole process can be well controlled. The house that meets the requirements as a simple earthquakeresistant healthy house, will get a simple earthquake-resistant home identity, certificate and book history of the construction of the house. In addition, through the 
strict control throughout the construction process, local testing is also conducted on the strength of concrete using a hammer test by housing experts. Second, preparation of accountability report. The responsibility of the physical and financial performance shall be the responsibility of the relevant KSM-P. In relation thereto, KSM-P is given training on accounting procedures and financial management in the use of BDR and construction implementation. Third, the management of complaints and conflict resolution. The management of complaints and conflict resolution is part of the effort to encourage the implementation of the program to run in accordance with the provisions and principles of honesty, fairness, transparency and stakeholdership to the weak (Interview with Mr. Sani Staff DMC JRF).

\subsection{Discussion}

The implementation of this model is done by first creating community groups consisting of several people, making decisions submitted to the community, and implementation philosophy based on local wisdom. Participation of the community can be grouped into three parts, namely, in the form of ideas or important ideas, property and objects owned by the community, and energy and time. Most of the people willingly devote all the abilities they possess in the form of thoughts, ideas, possessions and manpower in house rehabilitation and reconstruction activities. The active participation of the community in rehabilitation and reconstruction activities can be well realized due to several factors, namely: (1) The focus and objectives of the program are in accordance with the urgency of the community's primary needs; (2) The approach model chosen is a community-based approach that is appropriate to the condition and culture of the local community; (3) The existence of advisory systems (supervision and monitoring) encourages the emergence of optimistic nature of society in building; (4) The public trust in the government program; (5) The spirit of community independence (confidence). Figure 1 below shows the flow management of rehabilitation after the earthquake.

\section{Conclution}

The research draws conclusions as follows: First, a poor society, from an economic point of view, has always been the most vulnerable in every event of natural disaster like earthquakes. Humans do not have the ability to predict when and where earthquakes will occur, however one can estimate the locations that are prone to earthquakes. Second, the choice of disaster management model is crucial in determining the success of disaster management. Policy makers (stakeholders I actors) consisting of government or non-government bodies directly involved in public policy decisions have a very important position in determining the management model that is appropriate to the real situation and the social condition of the people.

\section{References:}


Anderson, J.E. 2000. Public Policy making: An Introduction, Fourth Edition. New York: Houghton Mifflin Company.

Bogdan, R.C. \& Biklen, S.K. 1988. Qualitative Research for Education: An Introduction to Theory and Methods, Third Edition. Boston: Allyn and Bacon, Inc.

Chase, R.B., Jacobs, F.R. and Aquilano, N.J. 2004. Operations Management for Competitive Advantage. New York: McGraw-Hill.

Don, L. \& Leet, F. 2006. Gempa Bumi. Jakarta: Kreasi Wacana.

Dunn, W.N. 1994. Public Policy Analysis: An Introduction, Second edition. New Jersey: Prentice Hall.

Hoeffler, S. and Keller, K.L. 2013. The Marketing Advantages of Strong Brands. The Journal of Brand Management, 10(6), 421-445.

Hofstede, G. 2014. Management styles and organizational effectiveness: An appraisal of private enterprises in Eastern Nigeria. American International Journal of Contemporary Research, 2(9), 198-204.

Jung, D.I., Bass, B.M. and Sosik, J.J. 1995. Bridging leadership and culture: A theoretical consideration of transformational leadership and collectivistic cultures. The Journal of Leadership Studies, 2(4), 3-18.

Karnawati, D. 2007. Anticipating Geological Hazards in Spatial Contexts. Yogyakarta.

Locander, W.B., Hamilton, F.D.L. 2012. Developing a leadership- rich culture: The missing link to creating a market-focused organization. Journal of Market-Focused Management, 20(2), 149-160.

Mikkelsen, B. 2003. Participatory Research Methods and Empowerment Efforts: A Handbook for Field Practitioners. Jakarta: Indonesian Torch Foundation.

Miles, B.M. and Huberman, M. 1992. Qualitative Research Methods. Jakarta: UI Press.

Moleong, L.J. 2006. Qualitative Research Methodology. Bandung: Rosda Karya.

Mubyarto, A. \& Kartodirjo, S. 1981. Rural Development in Indonesia. Yogyakarta: Liberty.

Mulya, H., Sukoharsono, E.G.A. and Djamhuri, Z.B. 2016. Qualitative Research Methods: Treasury Accounting Sultan Syarif Kasim Era Kingdom Siak Sri Inderapura Riau (1908-1946). Jakarta. Indonesia: Mitra Wacana Media Press.

Naryanto, Sri, H. 1999. Earthquakes and how to overcome them. Jakarta: Agency for the Assessment and Application of Technology.

Sudibyakto, H.A. 2000. Earthquake Analysis: Case Study of the Bengkulu Earthquake. Yogyakarta: UGM PSBA and IKPMPB.

Sunarto, A. 2008. Earthquake Prevention and Mitigation Based on Legislation in Indonesia. In D. Karnawati \& S. Pramumijoyo (Eds.), Proceedings of the Disaster Workshop. Earth Earthquake Risk Reduction Strategy. Yogyakarta: LPPM UGM-Hilink ProjectDepartment of Geological Engineering UGM- British Council.

Yin, R.K. 2003. Studi Kasus (Desain dan Metode). Jakarta: Raja Grafindo Persada 
Figure 1. Flow management of rehabilitation after the earthquake
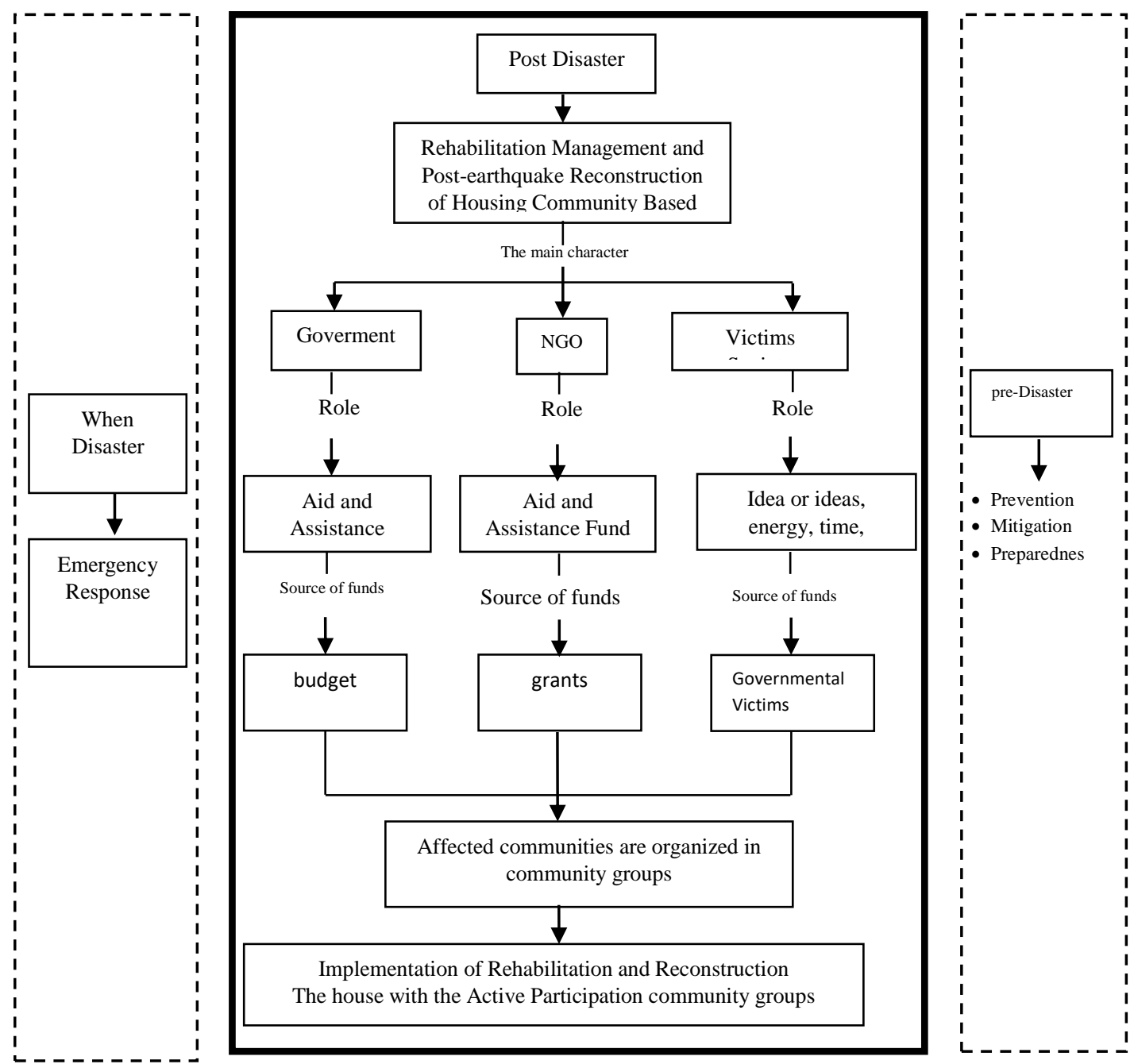